\title{
VARIASI PERBANDINGAN SEMEN DAN AGREGAT KASAR TERHADAP KUAT TEKAN DAN POROSITAS BETON BERPORI
}

\author{
Dandi Dwi Satrio ${ }^{1 *}$, Gusneli Yanti ${ }^{2}$, Shanti Wahyuni Megasari ${ }^{3}$ \\ Program Studi Teknik Sipil, Universitas Lancang Kuning Pekanbaru ${ }^{1}$ \\ Dosen Program Studi Teknik Sipil, Universitas Lancang Kuning Pekanbaru ${ }^{23}$ \\ JI. Yos Sudarso KM.8 Pekanbaru 28266 \\ E-mail: dandidwis@gmail.com¹, gusneli@unilak.ac.id², shanti@unilak.ac.id ${ }^{3}$
}

\begin{abstract}
Abstrak
Beton berpori memiliki nilai porositas tinggi yang terbuat dari semen, air dan agregat kasar. Salah satu karakteristik beton berpori adalah perbandingan semen dan agregat kasar. Penelitian ini bertujuan untuk mengetahui nilai kuat tekan dan porositas. Penelitian ini menggunakan metode $A C l-522 R-10$ dengan menggunakan agregat kasar ukuran $0,5-1 \mathrm{~cm}, 1-2 \mathrm{~cm}$ dan 2-3 cm. Perbandingan semen dan agregat kasar yang digunakan adalah 1:3, 1:4, 1:5, 1:6. Benda uji berbentuk silinder dengan diameter $15 \mathrm{~cm}$ dan tinggi $30 \mathrm{~cm}$. Hasil porositas yang didapat pada semua campuran sudah masuk kedalam angka 15\% - 35\% dimana sesuai berdasarkan $A C I 522 R-10$. Hasil kuat tekan tertinggi terdapat pada campuran VIII sebesar 16,03 MPa masuk syarat bata ringan mutu C dengan kuat tekan minimal $12,5 \mathrm{MPa}$ digunakan untuk pejalan kaki.
\end{abstract}

Kata kunci: Beton berpori, Kuat tekan, Porositas

\section{PENDAHULUAN}

Pertumbuhan populasi menurut Badan Pusat Statistik Provinsi Riau periode 2010 2018 dalam katalog Provinsi Riau Dalam Angka (2019) adalah 2,54 \%. Oleh karena itu, permintaan akan fasilitas dan infrastruktur yang layak seperti perumahan, tempat ibadah, jalan, tempat parkir, dan sebagainya telah meningkat. Hal ini menyebabkan berkurangnya lahan terbuka sebagai daerah tangkapan air. Pengurangan di daerah tangkapan air ini menghasilkan keterlambatan dalam proses menyerap air ke tanah, terutama selama musim hujan. Akibatnya, air tergenang di permukaan tanah dan menyebabkan banjir.

Salah satu solusi untuk mencegah dampak negatif ini adalah dengan menggunakan beton berpori, yang digunakan di tempat parkir, trotoar, jalan setapak, lapangan olahraga, taman, teras kolam renang dan bahu jalan (Obla, 2007). Pada beton berpori, terdapat beberapa variabel yang mempengaruhi karakteristiknya yaitu ukuran agregat kasar, komposisi persentase agregat kasar, faktor air semen dan perbandingan semen dengan agregat kasar (Kardiyono, 2007).

Beton berpori memiliki sifat fisik dan mekanis, sifat fisik beton berpori adalah porositas, dan sifat mekanisnya adalah kuat tekan. Porositas adalah persentase pori dalam beton relatif terhadap total volume beton. Kuat tekan beton berpori memiliki hubungan erat dengan porositas. Hubungan antara porositas dan kuat tekan adalah semakin kecil porositas, semakin tinggi kuat tekan beton berpori, sebaliknya semakin besar porositas, semakin rendah kuat tekan beton berpori (Shandy \& Hermanto, 2019).

Melihat dari latar belakang tersebut, dilakukan penelitian tentang kuat tekan dan porositas beton berpori dengan variasi perbandingan semen dan agregat kasar menggunakan agregat kasar tidak seragam.

\section{DASAR TEORI}

\section{Beton Berpori}

Beton berpori adalah jenis beton yang tidak biasa karena terbuat dari sejumlah air, dan semen yang digunakan dimonitor secara ketat untuk membentuk padatan seperti pasta yang membungkusnya di sekitar partikel agregat kasar. Tidak seperti beton biasa yang ditemukan, campuran ini tidak menggunakan pasir. Tujuannya adalah untuk menghasilkan sejumlah besar rongga udara antara $15-35 \%$ (ACI 552R-10, 2010).

Beton berpori adalah jenis beton khusus dengan porositas tinggi yang memungkinkan air hujan dan sumber air lainnya melewatinya, sehingga mengurangi limpasan permukaan dan meningkatkan muka air tanah (National 
ready mixed concrete association (NRMCA), 2004).

No fines concrete atau beton non-pasir adalah bentuk sederhana dari jenis beton ringan yang tidak menggunakan agregat halus (pasir) dalam pembuatannya. Tidak adanya agregat halus dalam campuran menghasilkan beton berpori, sehingga mengurangi beratnya (Kardiyono, 2007).

\section{Semen Portland}

Menurut (SNI 15-2049-2004, 2004), semen merupakan suatu jenis bahan yang mengandung sifat adhesif (adhesive) dan kohesif (cohesive) sehingga memungkinkan pecahan-pecahan mineral melekat menjadi sebuah massa yang padat. Semen adalah bahan yang jadi dan apabila mengenai air akan mengeras dinamakan semen hidraulis (hydraulic cements).

Semen portland di Indonesia dibagi menjadi 5 jenis sesuai dengan tujuan penggunaan, diantaranya:

1. Jenis 1 , Semen dapat digunakan untuk semua aplikasi yang tidak memerlukan persyaratan khusus

2. Jenis 2, Semen dengan panas hidrasi sedang dan tahan terhadap sulfat. Semen ini cocok untuk daerah dengan suhu tinggi dan struktur drainase

3. Jenis 3 , Semen yang memperoleh kuat tekan tinggi dalam waktu yang singkat

4. Jenis 4, Semen dengan panas hidrasi rendah. Semen ini dipergunakan pada keperluan konstruksi yang perlu jumlah dan peningkatan panas harus diminimalkan. Cocok pada wilayah yang bersuhu panas

5. Jenis 5, Semen yang pemakaiannya membutuhkan ketahanan tinggi terhadap sulfat. Digunakan untuk beton di daerah di mana tanah dan air mengandung sulfat tinggi

\section{Air}

Menurut (SNI 03-2847-2002, 2002), air yang digunakan untuk campuran beton harus bersih dan bebas dari zat berbahaya, termasuk oli, asam, alkali, garam, zat organik atau zat berbahaya lainnya untuk beton atau tulangan. Air tidak dapat diminum tidak boleh digunakan pada beton, kecuali ketentuan berikut terpenuhi:

1. Pilihan rasio campuran beton harus didasarkan pada rasio campuran beton menggunakan sumber air yang sama

2. Hasil pengujian pada umur 7 dan 28 hari pada kubus uji mortar yang dibuat dari adukan dengan air yang tidak dapat diminum harus mempunyai sekurangkurangnya sama dengan $90 \%$ dari kekuatan benda uji yang dibuat dengan air yang dapat diminum

\section{Agregat Kasar}

Menurut (SNI 03-2847-2002, 2002), agregat kasar adalah kerikil yang dihasilkan oleh disintegrasi alami batu alam atau industri pengolahan kerikil, dan ukurannya antara $5 \mathrm{~mm}$ sampai dengan $40 \mathrm{~mm}$. Agregat kasar (kerikil) yang digunakan untuk membuat campuran beton harus memenuhi persyaratan berikut:

1. Kerikil harus terdiri dari partikel keras, tidak berpori dan memiliki sifat kekal (tidak akan rusak atau hancur oleh kondisi cuaca seperti sinar matahari atau hujan). Hanya ketika jumlah partikel pipih tidak melebihi $20 \%$ dari total berat agregat, agregat yang mengandung partikel pipih dapat digunakan

2. Jika agregat kasar digunakan untuk membuat beton, terkena kelembapan atau kelembapan konstan, atau bersentuhan dengan tanah lembab, agregat tidak boleh mengandung bahan alkali-reaktif. Agregat reaktif alkali dapat dibuat dari semen, dan kandungan alkali dihitung setara dengan kandungan natrium oksida tidak melebihi $0.6 \%$, atau bahan yang dapat mencegah ekspansi dapat ditambahkan. Zat ini dapat mengembang karena reaksi agregat alkali. Itu bisa dibuat menjadi beton

3. Agregat kasar tidak boleh mengandung bahan yang dapat merusak beton, seperti bahan yang sangat reaktif, dan harus dibuktikan dengan uji warna larutan $\mathrm{NaOH}$

4. Lumpur pada agregat kasar tidak boleh melebihi $1 \%$ (berat kering). Jika kandungan lumpur lebih besar dari $1 \%$, agregat kasar harus dicuci

\section{Aditif}

Aditif adalah bahan selain semen, air dan agregat, dan dapat ditambahkan sebelum atau selama pencampuran. Menambahkan aditif pada campuran beton tidak akan mengubah komposisi bahan lain, karena penggunaan aditif ini sering dapat menggantikan campuran beton itu sendiri. Karena tujuannya adalah untuk meningkatkan atau mengubah sifat-sifat dan karakteristik tertentu dari beton yang diproduksi, tren perubahan volume dan komposisi berat tidak akan langsung dibandingkan dengan komposisi awal beton tanpa bahan tambahan. (Antoni \& Paul, 2007).

Umumnya, aditif yang digunakan dalam beton dapat dibagi menjadi dua jenis, yaitu aditif kimia dan aditif mineral. Untuk 
menghasilkan beton dengan faktor air semen yang rendah tetapi masih mudah diproses, diperlukan aditif, salah satunya adalah penggunaan bahan kimia superplasticizers. Karena kemampuan untuk mengurangi konsumsi air yang tinggi, campuran beton dan aditif dapat menghasilkan kekuatan tekan yang lebih tinggi (Aprilianti \& Nadia, 2012).

\section{METODE PENELITIAN}

\section{Perencanaan Campuran Beton Berpori}

Metode yang digunakan dalam pembuatan beton berpori adalah $A C l$ 522R-10. Untuk agregat kasar yang digunakan yaitu campuran dengan ukuran $2-3 \mathrm{~cm}, 1-2 \mathrm{~cm}$, 0,5 - $1 \mathrm{~cm}$ dengan perbandingan 20:40:40 sesuai penelitian (Yusra, 2019) dan agregat kasar yang digunakan dalam keadaan bersih tanpa debu dan jenuh air. Untuk perbandingan semen dan agregat kasar digunakan 1:3; 1:4; 1:5; 1:6 sesuai penelitian (Dwita et al., 2017) dengan faktor air semen 0,30. Untuk penambahan SikaCim Concrete Additive digunakan variasi persentase $0,7 \%$ terhadap berat semen (Jamal et al., 2017), setelah ditambah dengan aditif maka jumlah air dikurangi hingga $15 \%$. Total benda uji yang dibuat sebanyak 24 benda uji dengan campuran dapat dilihat pada tabel 1 .

Tabel 1. Proporsi Campuran Beton Berpori

\begin{tabular}{|c|c|c|c|c|c|c|c|c|}
\hline \multirow[b]{2}{*}{ Campuran } & \multicolumn{2}{|c|}{ Perbandingan } & \multirow{2}{*}{$\begin{array}{l}\text { Semen } \\
\mathrm{Kg}\end{array}$} & \multicolumn{3}{|c|}{ Ukuran Agregat Kasar } & \multirow{2}{*}{$\begin{array}{l}\text { Air } \\
\mathrm{ml}\end{array}$} & \multirow{2}{*}{$\begin{array}{c}\text { Aditif } \\
\mathrm{ml}\end{array}$} \\
\hline & Semen & $\begin{array}{c}\text { Agregat } \\
\text { Kasar }\end{array}$ & & $\begin{array}{c}2-3 \\
\mathrm{~cm}\end{array}$ & $\begin{array}{c}1-2 \\
\mathrm{~cm}\end{array}$ & $\begin{array}{c}0,5-1 \\
\mathrm{~cm}\end{array}$ & & \\
\hline I & 1 & 6 & 3,4 & \multirow{8}{*}{4,0} & \multirow{8}{*}{8,1} & \multirow{8}{*}{8,1} & 750 & \multirow{4}{*}{0} \\
\hline II & 1 & 5 & 4,0 & & & & 950 & \\
\hline III & 1 & 4 & 5,0 & & & & 1250 & \\
\hline IV & 1 & 3 & 6,7 & & & & 1760 & \\
\hline V & 1 & 6 & 3,4 & & & & 640 & 20 \\
\hline VI & 1 & 5 & 4,0 & & & & 810 & 24 \\
\hline VII & 1 & 4 & 5,0 & & & & 1060 & 30 \\
\hline VIII & 1 & 3 & 6,7 & & & & 1490 & 40 \\
\hline
\end{tabular}

\section{Pembuatan dan Perawatan Beton Berpori}

Pembuatan benda uji bertujuan untuk memeriksa kekuatan beton yaitu kuat tekan dan porositas. Benda uji yang dibuat berbentuk silinder dengan ukuran diameter $15 \times 30 \mathrm{~cm}$, jumlah benda uji sebanyak 24 benda uji. Pencampuran beton dilakukan secara bertahap, agregat kasar dicampur dengan 50\% air dan semen selama 30 detik, kemudian ditambahkan aditif dan air yang tersisa diaduk lagi selama 30 detik. Setelah mencetak benda uji, dirawat dengan merendam selama 28 hari.

\section{HASIL DAN PEMBAHASAN}

\section{Pengujian Kuat Tekan Beton Berpori}

Berdasarkan (SNI 1974:2011, 2011), pengujian kuat tekan beton dapat dilakukan dengan cara berikut:

1. Ambil benda uji dari kolam bak air, bersihkan dari kotoran dengan kain lembab

2. Timbang berat dan ukuran benda uji

3. Lapisi capping permukaan atas dan bawah benda uji dengan mortar belerang

4. Letakkan benda uji pada mesin uji tekan

5. Jalankan mesin uji tekan

6. Melakukan pembebanan sampai benda uji menjadi hancur

7. Catat beban maksimum yang terjadi selama pengujian

8. Menghitung kuat tekan beton

Tabel 2 menunjukkan hasil uji kuat tekan beton berpori 
Tabel 2. Hasil Uji Kuat Tekan Beton Berpori

\begin{tabular}{|c|c|c|c|c|c|c|c|}
\hline \multirow[b]{2}{*}{ Campuran } & \multirow{2}{*}{$\begin{array}{c}\text { Aditif } \\
(\%)\end{array}$} & \multicolumn{2}{|c|}{ Perbandingan } & \multirow{2}{*}{$\begin{array}{c}\text { Luas Tekan } \\
\left(\mathrm{cm}^{2}\right)\end{array}$} & \multirow{2}{*}{$\frac{\text { Beban }}{\mathrm{kN}}$} & \multicolumn{2}{|c|}{ Kuat Tekan } \\
\hline & & Semen & $\begin{array}{c}\text { Agregat } \\
\text { Kasar }\end{array}$ & & & $(\mathrm{MPa})$ & Rata - Rata \\
\hline \multirow{3}{*}{1} & \multirow{12}{*}{0} & & & 176,79 & 65,00 & 3,68 & \\
\hline & & 1 & 6 & 176,79 & 85,00 & 4,81 & 4,24 \\
\hline & & & & 176,79 & 75,00 & 4,24 & \\
\hline \multirow{3}{*}{ II } & & & & 176,79 & 130,00 & 7,35 & \\
\hline & & 1 & 5 & 176,79 & 125,00 & 7,07 & 7,16 \\
\hline & & & & 176,79 & 125,00 & 7,07 & \\
\hline \multirow{3}{*}{ III } & & & & 176,79 & 190,00 & 10,75 & \\
\hline & & 1 & 4 & 176,79 & 190,00 & 10,75 & 10,65 \\
\hline & & & & 176,79 & 185,00 & 10,46 & \\
\hline \multirow{3}{*}{ IV } & & & & 176,79 & 200,00 & 11,31 & \\
\hline & & 1 & 3 & 176,79 & 195,00 & 11,03 & 11,03 \\
\hline & & & & 176,79 & 190,00 & 10,75 & \\
\hline \multirow{3}{*}{$\mathrm{V}$} & \multirow{12}{*}{0,7} & & & 176,79 & 95,00 & 5,37 & \\
\hline & & 1 & 6 & 176,79 & 85,00 & 4,81 & 5,28 \\
\hline & & & & 176,79 & 100,00 & 5,66 & \\
\hline \multirow{3}{*}{ VI } & & & & 176,79 & 165,00 & 9,33 & \\
\hline & & 1 & 5 & 176,79 & 140,00 & 7,92 & 8,81 \\
\hline & & & & 176,79 & 162,00 & 9,16 & \\
\hline \multirow{3}{*}{ VII } & & & & 176,79 & 235,00 & 13,29 & \\
\hline & & 1 & 4 & 176,79 & 210,00 & 11,88 & 12,16 \\
\hline & & & & 176,79 & 200,00 & 11,31 & \\
\hline \multirow{3}{*}{ VIII } & & & & 176,79 & 265,00 & 14,99 & \\
\hline & & 1 & 3 & 176,79 & 275,00 & 15,56 & 16,03 \\
\hline & & & & 176,79 & 310,00 & 17,53 & \\
\hline
\end{tabular}

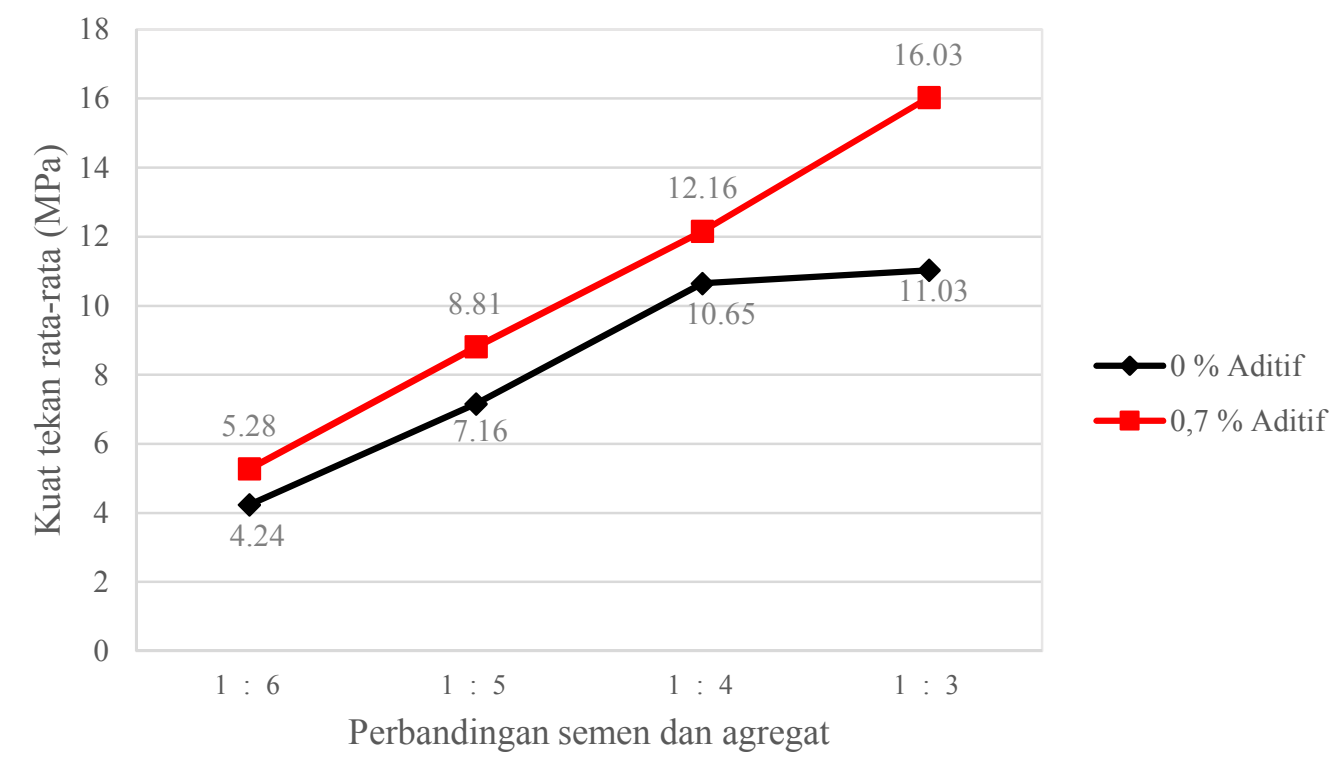

Gambar 1. Grafik Kuat Tekan Beton Berpori 
Dandi Dwi Satrio ${ }^{1 *}$, Gusneli Yanti ${ }^{2}$, dan Shanti Wahyuni Megasari ${ }^{3}$

Gambar 1 menunjukkan bahwa hasil kuat tekan rata-rata untuk campuran tanpa aditif yaitu campuran I $(1: 6)=4,24 \mathrm{MPa}$, campuran II $(1: 5)=7,16 \mathrm{MPa}$, campuran III $(1: 4)=10,65 \mathrm{MPa}$ dan campuran IV $(1: 3)=$ $11,03 \mathrm{MPa}$. Hasil kuat tekan rata-rata pada campuran yang memakai aditif yaitu campuran $\mathrm{V}(1: 6)=5,28 \mathrm{MPa}$, campuran $\mathrm{VI}(1: 5)=8,81$ MPa, campuran VII $(1: 4)=12,16 \mathrm{MPa}$ dan campuran VIII $(1: 3)=16,03 \mathrm{MPa}$. Hasil kuat tekan tertinggi campuran VIII (1:3) sebesar 16,03 MPa masuk syarat bata beton mutu C pada (SNI 03-0691-2001, 2001).

\section{Pengujian Porositas Beton Berpori}

Menurut (Musthofa, 2015), pengujian porositas dapat dilakukan dengan cara berikut:

1. Pertama pastikan benda uji dalam keadaan kering

2. Mengukur volume air pada akuarium pengujian

3. Setelah itu, benda uji dimasukkan ke akuarium yang dimodifikasi dengan saluran yang terhubung ke gelas ukur

4. Air yang berlebih akibat benda uji akan mengalir ke dalam gelas ukur

5. Untuk menghitung porositas, mengurangi volume total benda uji dengan volume air yang berpindah ke gelas ukur

Tabel 3 menunjukkan hasil uji porositas beton berpori

Tabel 3. Hasil Uji Porositas Beton Berpori

\begin{tabular}{|c|c|c|c|c|c|c|c|}
\hline \multirow[b]{2}{*}{ Campuran } & \multirow{2}{*}{$\begin{array}{c}\text { Aditif } \\
(\%)\end{array}$} & \multicolumn{2}{|c|}{ Perbandingan } & \multirow{2}{*}{$\begin{array}{c}\mathrm{T} \\
\text { (It) }\end{array}$} & \multirow{2}{*}{$\begin{array}{l}D \\
(I t)\end{array}$} & \multicolumn{2}{|c|}{ Porositas } \\
\hline & & Semen & $\begin{array}{c}\text { Agregat } \\
\text { Kasar }\end{array}$ & & & $\%$ & Rata - Rata \\
\hline \multirow{3}{*}{ I } & \multirow{12}{*}{0} & \multirow{3}{*}{1} & \multirow{3}{*}{6} & 5,30 & 3,55 & 33,02 & \multirow{3}{*}{29,37} \\
\hline & & & & 5,30 & 3,80 & 28,30 & \\
\hline & & & & 5,30 & 3,88 & 26,79 & \\
\hline \multirow{3}{*}{ II } & & \multirow{3}{*}{1} & \multirow{3}{*}{5} & 5,30 & 3,85 & 27,36 & \multirow{3}{*}{28,49} \\
\hline & & & & 5,30 & 3,79 & 28,49 & \\
\hline & & & & 5,30 & 3,73 & 29,62 & \\
\hline \multirow{3}{*}{ III } & & \multirow{3}{*}{1} & \multirow{3}{*}{4} & 5,30 & 4,09 & 22,83 & \multirow{3}{*}{23,90} \\
\hline & & & & 5,30 & 4,03 & 23,96 & \\
\hline & & & & 5,30 & 3,98 & 24,91 & \\
\hline \multirow{3}{*}{ IV } & & \multirow{3}{*}{1} & \multirow{3}{*}{3} & 5,30 & 4,15 & 21,70 & \multirow{3}{*}{22,45} \\
\hline & & & & 5,30 & 4,08 & 23,02 & \\
\hline & & & & 5,30 & 4,10 & 22,64 & \\
\hline \multirow{3}{*}{ V } & \multirow{12}{*}{0,7} & \multirow{3}{*}{1} & \multirow{3}{*}{6} & 5,30 & 3,73 & 29,62 & \multirow{3}{*}{28,87} \\
\hline & & & & 5,30 & 3,76 & 29,06 & \\
\hline & & & & 5,30 & 3,82 & 27,92 & \\
\hline \multirow{3}{*}{ VI } & & \multirow{3}{*}{1} & \multirow{3}{*}{5} & 5,30 & 3,76 & 29,06 & \multirow{3}{*}{27,99} \\
\hline & & & & 5,30 & 3,80 & 28,30 & \\
\hline & & & & 5,30 & 3,89 & 26,60 & \\
\hline & & & & 5,30 & 4,00 & 24,53 & \\
\hline VII & & 1 & 4 & 5,30 & 4,00 & 24,53 & 22,83 \\
\hline & & & & 5,30 & 4,27 & 19,43 & \\
\hline & & & & 5,30 & 4,11 & 22,45 & \\
\hline VIII & & 1 & 3 & 5,30 & 4,12 & 22,26 & 21,64 \\
\hline & & & & 5,30 & 4,23 & 20,19 & \\
\hline
\end{tabular}




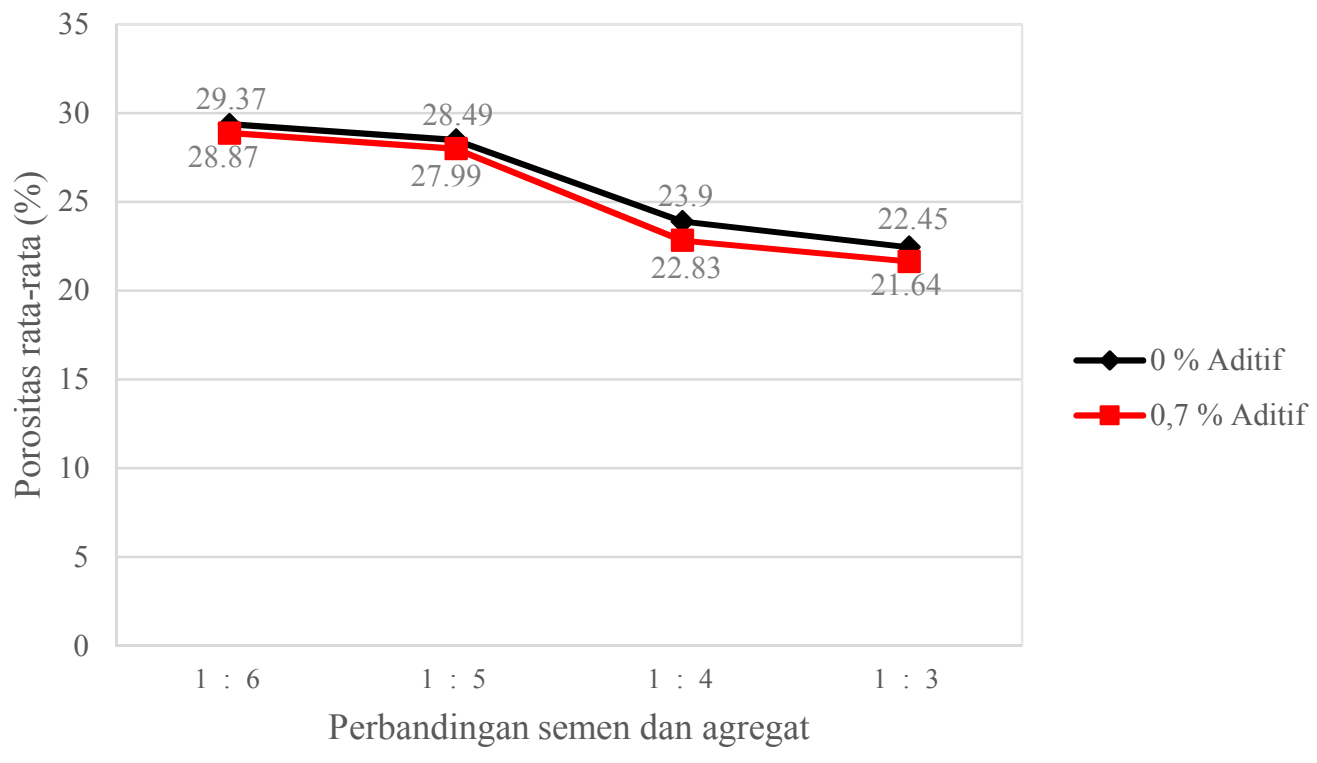

Gambar 2. Grafik Porositas Beton Berpori

Gambar 2 menunjukkan bahwa hasil porositas rata-rata pada campuran tanpa aditif yaitu campuran I $(1: 6)=29,37 \%$, campuran II $(1: 5)=28,49 \%$, campuran III $(1: 4)=23,90 \%$ dan campuran IV $(1: 3)=22,45 \%$. Hasil porositas rata-rata pada campuran yang memakai aditif yaitu campuran $\mathrm{V}(1: 6)=28,87$ $\%$, campuran VI $(1: 5)=27,99 \%$, campuran VII $(1: 4)=22,83 \%$ dan campuran VIII $(1: 3)=21,64$ $\%$. Hasil porositas yang didapat pada semua campuran sudah masuk kedalam range $15 \%$ $35 \%$ dimana sesuai berdasarkan (ACI 552R10, 2010).

\section{PENUTUP}

Dari penelitian yang dikerjakan dapat disimpulkan sebagai berikut:

1. Hasil uji kuat tekan tertinggi yang diperoleh dalam campuran VIII (1: 3 ) adalah $16,03 \mathrm{MPa}$, yang memenuhi persyaratan (SNI 03-0691-2001, 2001) bata beton mutu $\mathrm{C}$ sebesar $12,5 \mathrm{MPa}$ untuk pejalan kaki (sidewalk)

2. Hasil uji porositas tertinggi diperoleh pada campuran I (1:6) sebesar 29,37\%, memenuhi syarat batas untuk porositas pada beton berpori antara $15 \%-35 \%$ sesuai berdasarkan (ACI 552R-10, 2010)

Beberapa saran yang perlu disampaikan dari penelitian ini, diantaranya:

1. Perlu penelitian lebih lanjut dengan perbandingan semen dan agregat kasar yang sama, persentase aditif yang berbeda, untuk mendapatkan mutu yang lebih tinggi

2. Ketelitian dalam pembuatan dan pengujian beton berpori sangat dibutuhkan untuk mendapatkan hasil yang diinginkan

3. Diusahakan untuk meratakan adukan beton berpori pada bekisting saat pembuatan untuk memudahkan proses capping dengan menggunakan belerang, agar memperkuat ikatan antara benda uji dan capping serta menjaga keutuhan belerang agar tidak hancur sebelum ditekan

4. Perlu penelitian lebih lanjut tentang pengaruh penambahan bahan limbah pada campuran beton berpori terhadap kuat tekan dan porositasnya

\section{DAFTAR PUSTAKA}

ACl 552R-10. (2010). Report on pervious concrete, American concrete institute.

Antoni, \& Paul, N. (2007). Teknologi Beton. C.V Andi Offset.

Aprilianti, S., \& Nadia. (2012). Analisis Pengaruh Beton dengan Bahan Admixture Naphtalene dan Polycarboxilate Terhadap Kuat Tekan Beton Normal. Konstruksia, 3(2), $33-40$.

Dwita, E., Manalu, D. F., \& Sabri, F. (2017). Analisis Pengaruh Penggunaan Batu Pecah Granit Pulau Bangka terhadap Kuat Tekan dan Porositas Beton Berpori sebagai Bahan Penutup Halaman. Fropil, 5(2), 86-96.

Jamal, M., Widiastuti, M., \& Anugrah, A. T. (2017). Pengaruh Penggunaan Sikacim Concrete Additive Terhadap Kuat Tekan Beton dengan Menggunakan Agregat Kasar Bengalon dan Agregat Halus Pasir Mahakam. Prosiding Seminar Nasional 
Teknologi IV, 28-36.

Kardiyono, T. (2007). Teknologi Beton. Jurusan Teknik Sipil, Fakultas Teknik Universitas Gadjah Mada.

Musthofa, A. . (2015). Pengaruh Variasi Ukuran Gradasi Agregat Kasar Terhadap Kuat Tekan Beton Berpori. Universitas Jember.

National ready mixed concrete association (NRMCA). (2004). CIP 38 - Pervious Concrete. Concrete in Practice. What, Why and How?, 3.

Obla, K. H. (2007). Pervious Concrete for Sustainable Development. Proceedings of the 1st International Conference on Recent Advances in Concrete Technology, RAC 2007, 337-342.

Shandy, S., \& Hermanto, J. (2019). Studi Korelasi Porositas Beton Terhadap Kuat Tekan Beton Rata - Rata Menggunakan Agregat Kasar Batu Angus. Jurnal Teknik, 12(1), 72-83.

SNI 03-0691-2001. (2001). Bata Beton (Paving Block). In Badan Standarisasi Nasional.

SNI 03-2847-2002. (2002). Tata Cara Perhitungan Struktur Beton Untuk Bangunan Gedung. In Badan Standardisasi Nasional.

SNI 15-2049-2004. (2004). Semen Portland. In Badan Standar Nasional.

SNI 1974:2011. (2011). Cara Uji Kuat Tekan Beton dengan Benda Uji Silinder. In Badan Standarisasi Nasional.

Yusra, A. (2019). Studi Eksperimental Beton Porous Terhadap Nilai Kuat Tekan Beton. Universitas Lancang Kuning Pekanbaru. 